\title{
Peramalan Jumlah Kasus Demam Berdarah di Kabupaten Malang Menggunakan Metode Fuzzy Inference System
}

\author{
I Putu Agus Aditya Pramana, Wiwik Anggraeni, S.Si, M.Kom \\ Sistem Informasi, Fakultas Teknologi Informasi (FTIf), Institut Teknologi Sepuluh Nopember (ITS) \\ Jl. Arief Rahman Hakim, Surabaya 60111 Indonesia \\ e-mail:wiwik@its-sby.edu
}

\begin{abstract}
Abstrak-Demam berdarah Dengue (DBD) merupakan penyakit yang ditularkan ke manusia melalui gigitan nyamuk Aedes yang terinfeksi virus Dengue. Penyakit ini sudah menyebar luar ke seluruh Indonesia termasuk Kabupaten Malang. Pemerintah dan Dinas Kesehatan di Kabupaten Malang sudah melakukan berbagai upaya seperti pencegahan dan sosialisasi, namun masih terjadi kasus pasien yang meninggal akibat penyakit berbahaya ini. Peramalan jumlah kasus Demam Berdarah sangat penting dilakukan bagi pihak dinas kesehatan agar bisa membuat perencanaan untuk pencegahan dan pelayanan yang lebih matang dalam penanganan pasien di masa mendatang. Perencanaan tersebut diperlukan agar tidak terjadi masalah seperti keterlambatan tindakan pencegahan, bertambahnya korban jiwa dan kurangnya ruangan serta petugas untuk penanganan Demam Berdarah. Pada penelitian ini, digunakan metode Fuzzy Inference System untuk meramalkan jumlah kasus Demam Berdarah di kabupaten Malang. Metode Fuzzy Inference System ini cenderung memiliki nilai error yang kecil dan akurasi yang tinggi, karena proses dilakukan secara terperinci serta tidak hanya memperhatikan satu variabel. Selain itu tidak membutuhkan data yang banyak dan waktu yang lama. Peramalan dilakukan dengan memproses data jumlah kasus Demam Berdarah pada tiga kelompok kecamatan berdasarkan letak geografisnya tiap bulan dari beberapa tahun sebelumnya dengan melibatkan kepadatan penduduk. Data tersebut juga akan dibagi menjadi data train dan data test dengan perbandingan 70:30. Tugas akhir ini menghasilkan sebuah model peramalan jumlah kasus Demam Berdarah yang memiliki nilai MAPE pada tiap kelompok kecamatan di Dataran Rendah, Dataran Sedang, dan Dataran Tinggi adalah : $6 \%, 12 \%$, dan $14 \%$ sehingga hasil peramalan ini dapat dikategorikan baik. Hasil ini diharapkan dapat membantu pihak Dinas Kesehatan dalam pengambilan keputusan yang tepat di masa mendatang.
\end{abstract}

Kata Kunci- Peramalan, Demam Berdarah Dengue, Fuzzy Inference System

\section{PENDAHULUAN}

$\mathrm{D}$ EMAM Berdarah menjadi permasalahan kesehatan utama di Indonesia. Jumlah kasus dan penyebaran dari penyakit yang mematikan ini semakin bertambah seiring dengan meningkatnya mobilitas dan kepadatan penduduk. Jumlah penduduk Indonesia lebih dari 250 juta jiwa dan menempati urutan ke empat dalam Negara yang memiliki jumlah populasi tertinggi di Dunia. WHO mencatat negara Indonesia sebagai Negara dengan kasus Demam Berdarah tertinggi di Asia Tenggara [1] [2].

Dengan kondisi saat ini, pemerintah melakukan berbagai upaya untuk bisa menurunkan jumlah kasus Demam Berdarah. Bupati Malang membuat Peraturan Daerah
Nomor 2 Tahun 2011 tentang pengendalian penyakit Demam Berdarah Dengue di Kabupaten Malang [3]. Didalamnya terdapat kegiatan seperti penyuluhan dan sosialisasi mobilisasi untuk pemberantasan sarang nyamuk. Keberhasilan dari kegiatan ini dapat diukur dengan Angka Bebas Jentik (ABJ) dan Angka Kematian (AK) [1].

Hasil yang didapatkan masih belum optimal karena masih terdapat beberapa permasalahan. Meningkatnya jumlah penderita dan terdapat korban yang meninggal menunjukan kurang siapnya tindakan pencegahan yang dilakukan. Dinas Kesehatan masih menunggu laporan kasus Demam Berdarah sebelum melakukan fogging [4]. Alasan ini menjadikan perlu dibuatnya model-model kuatitatif yang menjelaskan dinamika dari jumlah kasus demam berdarah. Model dengan akurasi yang cukup dapat digunakan sebagai alat untuk pengambilan keputusan dan distribusi sumber daya untuk mengatasi epidemi [5] [6].

Peramalan penyakit Demam Berdarah pernah dilakukan sebelumnya di Thailand dan Kolumbia. Pada penelitian di Thailand menggunakan metode ARIMA namun hanya berfokus pada jumlah kasus Demam Berdarah dan tidak memperhatikan faktor lain yang memiliki dampak signifikan terhadap transmisi kasus demam berdarah. Sedangkan penelitian di Kolmubia menggunakan pendekatan fuzzy. Variabel yang digunakan ada dua, yaitu jumlah kasus Demam Berdarah yang tergolong ringan dan jumlah kasus Demam Berdarah yang tergolong parah. Model peramalan yang dibuat menunjukan pendekatan fuzzy dapat menghasilkan prediksi dan identifikasi yang akurat dan mendekati jumlah kasus yang sebenarnya [7] [8].

Metode Fuzzy Inference System tidak hanya digunakan untuk peramalan penyakit Demam Berdarah. Terdapat dua penelitian di Indonesia yang menggunakan model fuzzy untuk meramalkan dua objek yang berbeda. Objek penelitian yang dilakukan adalah jumlah produksi batik dan permintaan gas cair. Kedua penelitian ini menggunakan variabel lain yang berpengaruh untuk peramalan dan hasilnya akurat [9] [10].

Penelitian ini menggunaan metode Fuzzy Inference System dalam meramalkan jumlah kasus Demam Berdarah di Kabupaten Malang dengan melibatkan variabel kepadatan penduduk. Jumlah kasus Demam Berdarah dari kecamatan dikelompokkan menjadi tiga berdasarkan letak geografisnya, yaitu Dataran Rendah, Dataran Sedang, dan Dataran Tinggi. Pengelompokkan ini bertujuan untuk melihat pengaruh letak georafis kecamatan terhadap dinamika jumlah kasus demam Berdarah. 
Metode ini cenderung lebih cepat dan akurat daripada metode peramalan tradisional yang membutuhkan data yang banyak dan waktu yang lebih lama. Beberapa variabel yang berpengaruh terhadap peningkatan jumlah kasus Demam Berdarah juga bisa digunakan dalam proses peramalan. Selain itu dalam perbandingan dengan metode ANN dan SOM, pendekatan Fuzzy lebih memberikan hasil peramalan yang lebih baik [11].

Dinas Kesehatan Kabupaten Malang dapat menggunakan model peramalan ini sebagai deteksi dini peningkatan kasus Demam Berdarah untuk membentuk kebijakan kesehatan masyarakat seperti tindakan pencegahan. Data hasil peramalan bisa mendukung perencanaan untuk kebutuhan layanan kesehatan, peringatan untuk para petugas medis agar memberikan perawatan yang tepat waktu untuk pasien, dan ketersediaan obat-obatan atau jasa yang dibutuhkan di masa mendatang [12] [13].

\section{TINJAUAN PUSTAKA}

\section{A. Demam Berdarah Dengue}

Penyakit Demam Berdarah merupakan penyakit yang ditularkan ke manusia melalui gigitan nyamuk Aedes yang terinfeksi virus Dengue, terutama Aedes aegypti (Ae. Aegypti) dan Aedes albopictus (Ae. Albopictus). Gejala awal penderita demam berdarah mirip dengan flu (demam, mual, nyeri otot, dll). Demam Berdarah dapat berpotensi mematikan yang ditandai dengan pendarahan dan organ kerusakan parah [14]-[17]. Peningkatan gejala Demam Berdarah bisa dideteksi dini dengan membuat model peramalan yang bisa digunakan sebagai dasar untuk membentuk kebijakan kesehatan masyarakat seperti tindakan pencegahan.

\section{B. Kepadatan Penduduk}

Kepadatan penduduk adalah jumlah penduduk per satuan luas wilayahnya. Kepadatan penduduk kasar atau Crude Population Density (CPD) menunjukkan jumlah penduduk untuk setiap kilometer persegi luas wilayah [18]. Meningkatnya kepadatan penduduk membuat jumlah kasus dan penyebaran dari penyakit Demam Berdarah bertambah [1].

\section{Teknik Peramalan}

Peramalan (forecasting) merupakan suatu teknik yang digunakan untuk memprediksi atau memperkirakan suatu nilai pada masa depan dengan memperhatikan data atau informasi yang relevan pada masa lalu dan saat ini [19].

Metode peramalan dapat dibagi menjadi dua kategori, yaitu metode kualitatif dan metode kuantitatif. Metode kualitatif bersifat subjektif dan intuitif karena hanya memanfaatkan pendapat dari para ahli dan hasilnya tergantung orang yang menyusunnya. Sedangkan metode kuantitatif bersifat objektif dan dibuat berdasarkan data masa lalu [20].

\section{Logika Fuzzy}

Fuzzy mempunyai arti kabur atau tidak jelas. Jadi, logika fuzzy adalah logika yang kabur, atau mengandung unsur ketidakpastian. Logika fuzzy berbeda dengan teori logika tradisional, di mana set biner telah memiliki dua senilai logika, benar atau salah, variabel logika fuzzy mungkin memiliki nilai kebenaran yang berkisar di tingkat antara 0 dan $1[21]$.

\section{E. Himpunan Fuzzy}

Himpunan fuzzy memiliki nilai keanggotaan terletak pada rentang 0 dan 1. Pengelompokkan dilakukan berdasarkan variabel bahasa (linguistik variabel), yang dinyatakan dengan fungsi keanggotaan, dalam semesta pembicaraan [22].

\section{F. Fungsi Keanggotaan Fuzzy}

Didalam logika fuzzy, fungsi keanggotaan menyatakan derajat keanggotaan pada suatu himpunan. Fungsi keanggotaan adalah suatu kurva yang menunjukkan titiktitik input data kedalam nilai keanggotaan yang berada dalam interval 0 sampai 1 . Fungsi keanggotaan dinyatakan dengan $\mu \mathrm{A}$. Salah satu cara yang dapat digunakan untuk mendapatkan nilai keanggotaan adalah dengan melalui pendekatan fungsi [22].

\section{G. Sistem Inferensi Fuzzy}

Sistem kendai logika fuzzy disebut juga Sistem Inferensi Fuzzy (Fuzzy Inference System/FIS) adalah sistem yang dibuat untuk melakukan penalaran. Konsep dari sistem ini meniru manusia yang melakukan penalaran dengan nalurinya. FIS tebagi menjadi beberapa jenis, yaitu Tsukamoto, Mamdani, dan Sugeno. Mamdani sering dikenal sebagai model Max-Min merupakan FIS yang paling mudah dimengerti, karena paling sesuai dengan naluri manusia dan bekerja berdasarkan kaidah-kaidah linguistik. Keuntungan lain dari model ini adalah lebih intuitif, cocok menggunakan input dari manusia (bukan mesin), dan dapat diterima oleh banyak pihak [23].

\section{H. Evaluasi hasil peramalan}

Untuk mengetahui keakuratan hasil peramalan dilakukan evaluasi dengan menggunakan metode perhitungan kesalahan dalam peramalan. Mean Absolute Percentage Error (MAPE) merupakan perhitungan yang menunjukkan nilai rata-rata dari perbedaan data asli dan data hasil peramalan yang diabsolutkan dalam bentuk persentase. Semakin rendah nilai MAPE menunjukkan model peramalan memiliki kemampuan yang baik. Tabel 1 merupakan perbandingan tingkat akurasi hasil peramalan berdasarkan nilai MAPE [20].

Tabel 1.

Hasil peramalan berdasarkan nilai MAPE

\begin{tabular}{|l|l|}
\hline MAPE & Hasil Peramalan \\
\hline$<10 \%$ & Sangat Baik \\
\hline $10-20 \%$ & Baik \\
\hline $20-50 \%$ & Layak/ Cukup \\
\hline$>50 \%$ & Buruk \\
\hline
\end{tabular}

Rumus MAPE Secara umum dapat dituliskan [20] :

$$
\text { MAPE }=\frac{\sum_{t=1}^{n}=\frac{\mid x t-f r}{x t} \mid}{n} \times 100 \%
$$

Dimana:

MAPE $=$ Mean Absolute Percentage Error $\mathrm{n}=$ Jumlah Sampel 
$\mathrm{xt}=$ Nilai Aktual Indeks pada period ke-t

$\mathrm{ft}=$ Nilai Prediksi Indeks pada period ke-t

\section{Interpolasi}

Interpolasi merupakan metode untuk mengisi data yang kosong pada suatu interval data dengan melakukan perhitungan pada data sebelum dan sesudah dari interval yang memiliki data kosong.

Berikut rumus untuk melakukan interpolasi [24]:

$$
y=y 1+\frac{(x-x 1)(y 2-y 1)}{x 2-x 1}
$$

\section{METODE PENELITIAN}

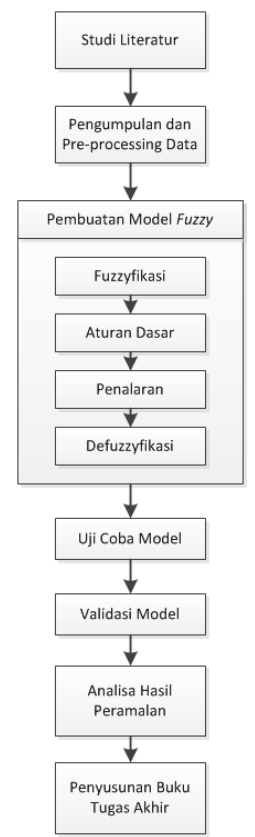

Gambar 1. Diagram Alur Metodologi Penelitian

\section{A. Pengumpulan dan Pre-processing Data}

Data jumlah kasus Demam Berdarah didapat dari Dinas Kesehatan Kabupaten Malang dalam bentuk excel, ditambahkan pula data kepadatan penduduk di Kabupaten Malang sebagai variabel tambahan. Data dari Dinas Kesehatan Kabupaten Malang adalah data bulanan per kecamatan pada tahun 2009-2014.

\section{B. Penerapan Metode Fuzzy}

- Fuzzyfikasi

Pada proses ini variabel input yang masih berupa nilai tegas akan dibuat menjadi himpunan fuzzy.

- Aturan Dasar

Pada proses ini aturan fuzzy dibangun dari setiap pasangan input dan output variabel yang menghasilkan aturan dalam bentuk implikasi IF.... THEN..".

- Penalaran

Proses implikasi ini menggunakan nilai input berupa hasil proses fuzzyfikasi untuk selanjutnya dilakukan operasi max-min.

- Defuzzyfikasi

Pada proses ini variabel berupa himpunan fuzzy dirubah menjadi output berupa himpunan tegas.

\section{Uji Coba Model}

Pada tahapan ini akan dilakukan skenario uji coba pada train set dengan beberapa jenis model yang sudah dibuat sebelumnya. Ada tiga skenario Uji Coba, yaitu : Uji Coba I, Uji Coba II, dan Uji Coba III. Pada tahap uji coba ini akan ditentukan model yang digunakan untuk peramalan.

\section{Validasi Model}

Pada tahapan ini model yang sudah dibuat akan divalidasi menggunakan test set. Hasil validasi akan menunjukkan model bisa digunakan untuk melakukan peramalan dengan data yang berbeda.

\section{E. Analisa Hasil Peramalan}

Pengukuran dilakukan dengan perhitungan MAPE setelah itu analisa mengenai peningkatan dan penurunan jumlah kasus Demam Berdarah.

\section{PERANCANGAN DAN IMPLEMENTASI}

\section{A. Pengolahan data}

Data jumlah kasus demam berdarah di Kabupaten Malang berupa data bulanan dari tahun 2009 - 2014. Dari 39 kecamatan yang ada dimalang akan dikelompokan menjadi 3 berdasarkan letak geografisnya, yaitu : dataran rendah, dataran sedang, dan dataran tinggi. Selain data jumlah kasus, data jumlah penduduk digunakan sebagai variabel yang mempengaruhi. Karena terdapat missing value dan kurangnya periode data, dilakukan interpolasi dan extend data [25].

\section{B. Pembuatan Model Fuzzy}

Untuk menghasilkan hasil peramalan pada tiga kelompok kecamatan dikabupaten malang, diperlukan tiga model peramalan yang berbeda. Tabel 2 menunjukan daftar variabel yang digunakan pada model beserta keterangannya.

Tabel 2.

Daftar Variabel beserta keterangannya

\begin{tabular}{|l|l|}
\hline Nama Variabel & Keterangan \\
\hline $\begin{array}{l}\text { Kasus DBD } \\
\text { dat.rendah }\end{array}$ & $\begin{array}{l}\text { Jumlah kasus DBD perbulan di } \\
\text { kelompok kecamatan di dataran } \\
\text { rendah. }\end{array}$ \\
\hline $\begin{array}{l}\text { Kasus DBD } \\
\text { dat.sedang }\end{array}$ & $\begin{array}{l}\text { Jumlah kasus DBD perbulan di } \\
\text { kelompok kecamatan di dataran } \\
\text { sedang. }\end{array}$ \\
\hline $\begin{array}{l}\text { Kasus DBD } \\
\text { dat.tinggi }\end{array}$ & $\begin{array}{l}\text { Jumlah kasus DBD perbulan di } \\
\text { kelompok kecamatan di dataran } \\
\text { tinggi. }\end{array}$ \\
\hline $\begin{array}{l}\text { Kepadatan } \\
\text { penduduk }\end{array}$ & $\begin{array}{l}\text { Jumlah penduduk perbulan di } \\
\text { kabupaten malang. }\end{array}$ \\
\hline $\begin{array}{l}\text { Peramalan kasus } \\
\text { DBD dat.rendah }\end{array}$ & $\begin{array}{l}\text { Hasil peramalan jumlah kasus } \\
\text { DBD perbulan di kelompok } \\
\text { kecamatan di dataran rendah. }\end{array}$ \\
\hline $\begin{array}{l}\text { Peramalan kasus } \\
\text { DBD dat. Sedang }\end{array}$ & $\begin{array}{l}\text { Hasil peramalan jumlah kasus } \\
\text { DBD perbulan di kelompok } \\
\text { kecamatan di dataran sedang. }\end{array}$ \\
\hline $\begin{array}{l}\text { Peramalan kasus } \\
\text { DBD dat. Tinggi }\end{array}$ & $\begin{array}{l}\text { Hasil peramalan jumlah kasus } \\
\text { DBD perbulan di kelompok } \\
\text { kecamatan di dataran tinggi. }\end{array}$ \\
\hline
\end{tabular}


Model fuzzy yang dibuat menggunakan variabel kasus demam berdarah dan jumlah penduduk menjadi variabel masukan dan variabel peramalan kasus demam berdarah menjadi variabel keluaran. Pada Himpunan fuzzy untuk variabel kepadatan penduduk hanya memiliki himpunan fuzzy pertumbuhan karena bentuk representasinya fungsi keanggotaannya berupa kurva-s. Himpunan fuzzy untuk variabel peramalan jumlah kasus demam berdarah dibagi menjadi tujuh himpunan, yaitu : Very Very Low (VVL), Very Low (VL), Low (L), Normal (N), High (H), Very High (VH), Very Very High (VVH).

Berikut merupakan salah satu model yang dibuat untuk kelompok kecamatan di dataran rendah:

Gambar 2 merupakan bentuk representasi variabel kasus DBD dataran rendah yang menjadi variabel masukan model. Fungsi keanggotaan menggunakan tipe bahu, yaitu kombinasi dari bentuk trapesium dan segitiga. Himpunan VVL memiliki batasan fungsi keanggotaan yang digambarkan oleh garis biru pada sisi paling kiri yang menunjukkan tipe representasi berbentuk trapesium pada sisi kiri. Himpunan VL, L, N, H, VH memiliki batasan fungsi keanggotaan yang digambarkan oleh garis berwarna merah muda yang menunjukkan tipe representasi berbentuk segitiga. Himpunan VVH memiliki batasan fungsi keanggotaan yang digambarkan oleh garis berwarna hijau yang menunjukkan tipe representasi berbentuk trapesium pada sisi kanan. Detail dari batasan fungsi keanggotaan variabel masukan model dataran rendah dapat dilihat pada Gambar 4.

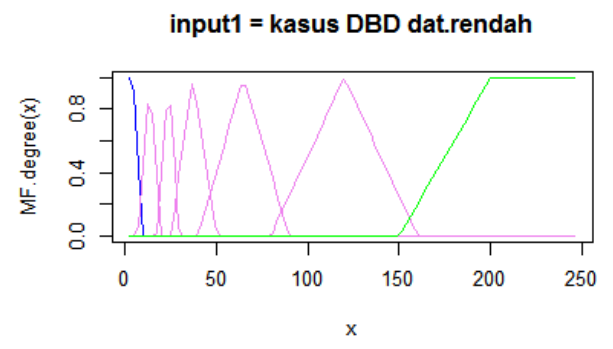

Gambar 2 Input 1 Model Dataran Rendah

Gambar 3 merupakan bentuk representasi variabel kepadatan penduduk yang menjadi variabel masukan model. Fungsi keanggotaan menggunakan tipe kurva-s. Kurva ini menunjukkan himpunan pertumbuhan. Detail dari batasan fungsi keanggotaan variabel masukan model dataran rendah dapat dilihat pada Gambar 5.4.

\section{input2 = kepadatan penduduk}

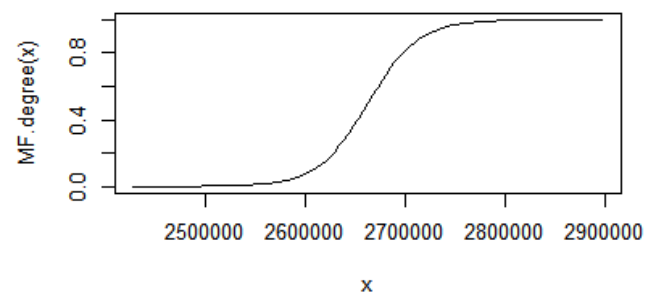

Gambar 3. Input 2 Model Dataran Rendah

Gambar 4 merupakan batasan fungsi keanggotaan yang menunjukkan range dari himpunan fuzzy-nya masing-masing dari variabel masukan model dataran rendah. Baris pertama adalah tipe fungsi keanggotaan, dimana 1 berarti segitiga, 2 berarti trapesium pada sisi kiri, 3 berarti trapesium pada sisi kanan, dan 6 berarti sigmoid. Sedangkan baris kedua hingga kelima berturut-turut menunjukkan titik sudut untuk membangun fungsi keanggotaan.

$\begin{array}{lrrrrrrrr}\text { \$varinp. mf } & & & & & \\ & \text { VVL } & \text { VL } & \text { L } & \text { N } & \text { H } & \text { VH } & \text { VVH } & \text { pertumbuhan } \\ {[1,]} & 2 & 1.00 & 1.00 & 1.0 & 1 & 1 & 3 & 6.000000 e+00 \\ {[2,]} & 0 & 7.50 & 17.50 & 25.0 & 40 & 80 & 150 & 4.000000 e-05 \\ {[3,]} & 5 & 13.75 & 23.75 & 37.5 & 65 & 120 & 200 & 2.663042 \mathrm{e}+06 \\ {[4,]} & 10 & 20.00 & 30.00 & 50.0 & 90 & 160 & 250 & \text { NA } \\ {[5,]} & \text { NA } & \text { NA } & \text { NA } & \text { NA } & \text { NA } & \text { NA } & \text { NA } & \text { NA }\end{array}$

Gambar 4. Batasan Fungsi Keanggotaan Input Model Dataran Rendah

Gambar 5 merupakan bentuk representasi variabel kasus DBD dataran rendah yang menjadi variabel keluaran model. Fungsi keanggotaan menggunakan tipe bahu, yaitu kombinasi dari bentuk trapesium dan segitiga. Himpunan VVL memiliki batasan fungsi keanggotaan yang digambarkan oleh garis biru pada sisi paling kiri yang menunjukkan tipe representasi berbentuk trapesium pada sisi kiri. Himpunan VL, L, N, H, VH memiliki batasan fungsi keanggotaan yang digambarkan oleh garis berwarna merah muda yang menunjukkan tipe representasi berbentuk segitiga. Himpunan VVH memiliki batasan fungsi keanggotaan yang digambarkan oleh garis berwarna hijau yang menunjukkan tipe representasi berbentuk trapesium pada sisi kanan. Detail dari batasan fungsi keanggotaan variabel keluaran model dataran rendah dapat dilihat pada Gambar 6.

\section{output1 = peramalan kasus DBD dat.rendah}

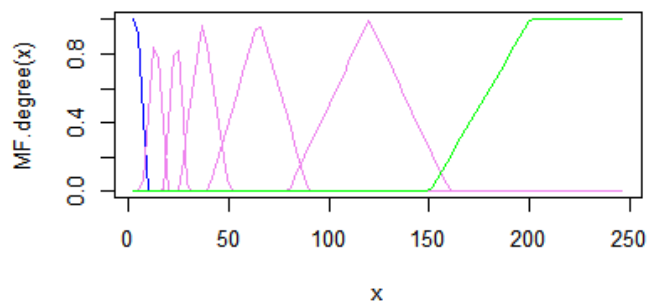

Gambar 5. Variabel Keluaran Model Dataran Rendah

Gambar 6 merupakan batasan fungsi keanggotaan yang menunjukkan range dari himpunan fuzzy-nya masing-masing dari variabel masukan model dataran rendah. Baris pertama adalah tipe fungsi keanggotaan, dimana 1 berarti segitiga, 2 berarti trapesium pada sisi kiri, dan 3 berarti trapesium pada sisi kanan. Sedangkan baris kedua hingga kelima berturutturut menunjukkan titik sudut untuk membangun fungsi keanggotaan.

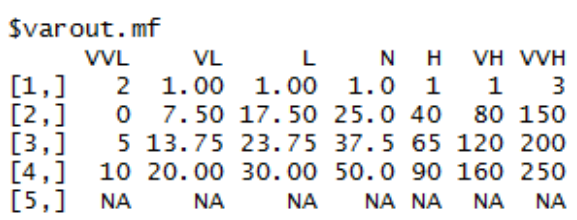

Gambar 6. Batasan fungsi keanggotaan Variabel Keluaran Model Dataran Rendah

Gambar 7 merupakan Range data dari variabel yang digunakan pada model dataran rendah yang menunjukkan semesta pembicaraan dari setiap variabel. Kolom 1 
merupakan range data pada variabel input 1, kolom 2 merupakan range data pada variabel input 2, dan kolom 3 merupakan range data pada variabel output. Baris 1 menunjukkan nilai terkecil, dan Baris 2 menunjukkan nilai terbesar dari data.

$$
\begin{aligned}
& \$ r \text { ange. data. or } i \\
& {[, 1] \quad[, 2][, 3]} \\
& {[1,] \quad 3 \quad 2428283} \\
& {[2,] \quad 246 \quad 2897800 \quad 246}
\end{aligned}
$$

Gambar 7. Range Data Variabel Model Dataran Rendah

Tabel 3 merupakan aturan fuzzy yang diterapkan pada semua model :

Tabel 3.

Daftar aturan fuzzy

\begin{tabular}{|l|l|}
\hline No & Aturan Fuzzy \\
\hline 1. & $\begin{array}{l}\text { "IF" "input1" "is" "VVL" "and" "input2" "is" } \\
\text { "pertumbuhan" "THEN" "output1" "is" "VVL" }\end{array}$ \\
\hline 2. & $\begin{array}{l}\text { "IF" "input1" "is" " VL" "and" "input2" "is" } \\
\text { "pertumbuhan" "THEN" "output1" "is" "VL" }\end{array}$ \\
\hline 3. & $\begin{array}{l}\text { "IF" "input1" "is" "L" "and" "input2" "is" } \\
\text { "pertumbuhan" "THEN" "output1" "is" "L" }\end{array}$ \\
\hline 4. & $\begin{array}{l}\text { "IF" "input1" "is" "N" "and" "input2" "is" } \\
\text { "pertumbuhan" "THEN" "output1" "is" "N" }\end{array}$ \\
\hline 5. & $\begin{array}{l}\text { "IF" "input1" "is" "H" "and" "input2" "is" } \\
\text { "pertumbuhan" "THEN" "output1" "is" "H" }\end{array}$ \\
\hline 6. & $\begin{array}{l}\text { "IF" "input1" "is" " VH " "and" "input2" "is" } \\
\text { "pertumbuhan" "THEN" "output1" "is" "VH" }\end{array}$ \\
\hline 7. & $\begin{array}{l}\text { "IF" "input1" "is" " VVH " "and" "input2" "is" } \\
\text { "pertumbuhan" "THEN" "output1" "is" "VVH" }\end{array}$ \\
\hline
\end{tabular}

\section{UJI COBA DAN ANALISIS HASIL}

Pada tahap membuat uji coba model sudah dibuat tiga skenario Uji Coba yang berbeda. Uji Coba I merupakan model yang dirancang dengan variabel jumlah kasus demam berdarah memiliki fungsi keanggotaan yang batasannya dibuat simetris. Uji Coba II merupakan model yang dirancang dengan variabel jumlah kasus demam berdarah memiliki fungsi keanggotaan yang batasannya dibuat sesuai dengan persebaran data. Uji Coba III merupakan model yang dirancang dengan variabel kepadatan penduduk memiliki representasi fungsi keanggotaan yang berbentuk kurva linear.

Tabel 4.

Perbandingan MAPE Model Uji Coba

\begin{tabular}{|l|l|l|}
\hline Model Uji Coba & Training set & Test set \\
\hline Uji Coba I & $38 \%$ & $38 \%$ \\
\hline Uji Coba II & $11 \%$ & $13 \%$ \\
\hline Uji Coba III & $14 \%$ & $13 \%$ \\
\hline
\end{tabular}

Tabel 4 menunjukkan model uji coba II memiliki nilai error pada train set paling kecil sehingga menjadi model terbaik yang akan digunakan untuk peramalan, selain itu nilai error yang kecil pada test set yang menunjukan model sudah valid dan siap digunakan untuk meramal data lain. Grafik hasil peramalan tahun 2015 pada kelompok kecamatan dataran rendah dapat dilihat pada gambar 8. Hasil peramalan tiap kelompok kecamatan dapat dilihat pada Tabel 5.

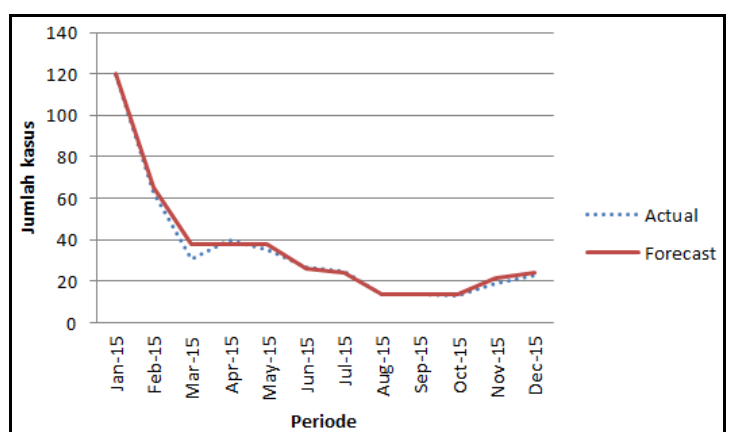

Gambar 8. Grafik Hasil Peramalan Jumlah Kasus DBD Dataran Rendah

Tabel 5.

Perhitungan MAPE Pada Hasil Peramalan

\begin{tabular}{|l|c|}
\hline Hasil peramalan & MAPE \\
\hline $\begin{array}{l}\text { Peramalan jumlah kasus DBD pada kelompok } \\
\text { kecamatan di Dataran Rendah }\end{array}$ & $6 \%$ \\
\hline $\begin{array}{l}\text { Peramalan jumlah kasus DBD pada kelompok } \\
\text { kecamatan di Dataran Sedang }\end{array}$ & $12 \%$ \\
\hline $\begin{array}{l}\text { Peramalan jumlah kasus DBD pada kelompok } \\
\text { kecamatan di Dataran Tinggi }\end{array}$ & $14 \%$ \\
\hline
\end{tabular}

Tabel 5 menunjukan hasil peramalan untuk jumlah kasus DBD dataran rendah tergolong sangat baik karena nilai MAPE dibawah $10 \%$, sedangkan hasil peramalan untuk jumlah kasus DBD dataran sedang dan tinggi masih tergolong Baik karena nilai MAPE masih dibawah $20 \%$.

\section{KESIMPULAN/RINGKASAN}

Berdasarkan hasil penelitian , maka didapatkan kesimpulan :

1. Peramalan jumlah kasus demam berdarah dengan menggunakan metode Fuzzy Inference System pada tiap kelompok kecamatan menghasilkan akurasi peramalan terbaik dengan menggunakan model skenario Uji Coba II yang batasannya fungsi keanggotaan dibuat sesuai dengan persebaran data dan menggunakan kurva-s untuk variabel jumlah penduduk.

2. Bentuk representasi fungsi keanggotaan variabel kepadatan penduduk mempengaruhi akurasi hasil peramalan jumlah jumlah kasus demam berdarah, dimana variabel kepadatan penduduk lebih cocok menggunakan bentuk kurva-s dibanding kurva linear.

3. Jumlah himpunan fuzzy dan batasan dari himpunan fuzzy sangat berpengaruh pada hasil peramalan. Batasan yang optimal dan sesuai dengan pola data akan menghasilkan peramalan yang baik.

4. Nilai MAPE pada Peramalan jumlah kasus DBD pada tiap kelompok kecamatan di Dataran Rendah, Dataran Sedang, dan Dataran Tinggi adalah : 6\% (sangat baik), $12 \%$ (baik), dan 14\% (baik). Nilai ini didapat dengan membandingkan data hasil peramalan dengan data aktual berupa nilai rata-rata jumlah kasus perbulan dari tahun 2009-2014.

5. Variabel kepadatan penduduk tidak memberi pengaruh yang signifikan terhadap hasil peramalan jumlah kasus Demam Berdarah. 
Saran yang diajukan dalam artikel ini untuk penelitian selanjutnya, yaitu:

1. Objek penelitian dapat dikembangkan menjadi lebih luas menjadi membuat model peramalan jumlah kasus demam berdarah di Provinsi Jawa Timur.

2. Data yang digunakan bisa berupa data mingguan ataupun harian, agar data yang diproses lebih banyak sehingga bisa membuat model yang hasilnya lebih akurat.

3. Pengelompokkan pada daerah observasi dapat dibuat lebih mendetail berdasarkan karakter yang dimiliki daerah masing-masing.

4. Variabel lain yang digunakan sebaiknya memberi pengaruh yang signifikan dan memiliki fungsi keanggotaan yang lebih mendetail sehingga dapat membuat aturan (rules) yang lebih banyak untuk mengoptimalkan hasil peramalan.

5. Dalam menentukan model untuk peramalan Fuzzy Inference System masih dilakukan secara manual, kedepannnya dapat digunakan metode atau tools lain yang bisa membuat proses peramalan lebih optimal.

\section{UCAPAN TERIMA KASIH}

Terima kasih kepada Tuhan Yang Maha Esa atas segala rahmat dan semua pihak yang mendukung penelitian ini, Jurusan Sistem Informasi, Fakultas Teknologi Informasi, ITS.

\section{DAFTAR PUSTAKA}

[1] Pusat Data dan Surveilance Epidemiologi Kementrian Kesehatan Republik Indonesia, "Jendela Epidemiologi," Kementrian Kesehatan Republik Indonesia, Jakarta, 2010.

[2] Internet Worlds Stats. (2015, Agustus) The World Population And The Top Ten Countries With The Highest Population. [Online]. http://www.internetworldstats.com/stats8.htm

[3] Bupati Malang, "Peraturan Bupati Malang Nomor 2 Tahun 2011 tentang Pengendalian Penyakit Demam berdarah Dengue di Kabupaten Malang," Pemerintah Kabupaten Malang, Malang, 2011.

[4] Malang Post. (2015, Agustus ) Masyarakat Was-was Demam Berdarah, Malang. [Online]. http://www.malang-post.com/kotamalang/98588-masyarakat-was-was-demam berdarah

[5] Barrios J, Pietrus A, Marrero A, de Arazoza H, Joya G, "Dengue model described by differential inclusions," in Advances in computational intelligence, Rojas I, Joya G Cabestany J, Ed. Berlin: Springer, 2011, pp. 540-7.

[6] Whitehead S, Durbin A, "Prospects and challenges for dengue virus vaccine," in Frontiers in dengue virus, Weaver S Hanley K, Ed. Norfolk: Caister Academic Press, 2010.

[7] M.J Siriwan Wongkoon, "Development of temporal modeling for prediction of dengue infection," Asian Pacific Journal of Tropical Medicine, 2012.

[8] Torres, Claudia, et al, "Fuzzy model identification of dengue epidemic in Colombia based on multiresolution analysis," Universidad Distrital Francisco José de Caldas, Colombia, 2013.

[9] E D Arifah, "Aplikasi Metode Fuzzy Mamdani dalam Penentuan Jumlah Produksi," Institut Teknologi Sepuluh Nopermber, Surabaya, 2011.

[10] Khikmiyah L, Anggraini W, Vinarti R A, "Prediksi Permintaan Gas Cair Menggunakan Fussy Inference Model pada PT Air Products Gresik," Institut Teknologi Sepuluh Nopember, Surabaya, 2012.

[11] A.K. Lohani, "Improving real time flood forecasting using fuzzy inference system," Indian Institute of Technology, India, 2014.

[12] Rothman K, Greenland S, Lash T, "Modern epidemiology,"
Lippincott Williams \& Wilkins, Philadelphia, 2008.

[13] Lee L, Teutsch S, Thacker S, Louis MS, "Principles and practice of public health," Oxford University Press, New York, 2000.

[14] Hay SI, Myers MF, Burke DS, Vaughn DW, Endy T, Ananda N, et al;, "Ethology of interepidemic periods of mosquito-borne disease," Proc Nat Acad Sci USA, no. 97, pp. 9335-9339, 2000.

[15] Stephenson I, Roper J, Fraser M, Nicholson K, Wiselka M, "Dengue fever in febrile returning travelers to a UK regional infectious diseases unit," Travel Med Infect Dis, vol. 1, pp. 89-93, 2003.

[16] WHO, "Dengue: Guidelines for diagnosis, treatment, prevention and control," France, WHO and TDR Publication 2009.

[17] George R, Lum L, "Clinical spectrum of dengue infection," in Dengue and dengue hemorrhagic fever, Kuno G Gubler D, Ed. New York: CAB International, 1997, pp. 89-113.

[18] Badan Pusat Statistik. (2015, Agustus) Istilah Kepadatan Penduduk, Badan Pusat Statistik. [Online]. http://www.bps.go.id/index.php/istilah/211

[19] N. Nachrowi, Teknik Pengambilan Keputusan. Jakarta: Grasindo, 2004.

[20] S. Makridakis, Metode dan Aplikasi Peramalan Edisi Kedua. Jakarta: Erlangga, 1998.

[21] L.A. Zadeh, "Fuzzy Sets," University of California, California, 1965.

[22] Kusumadewi, S., Purnomo H, Aplikasi Logika Fuzzy untuk Pendukung Keputusan. Yogyakarta: Graha Ilmu, 2004.

[23] S. Kusumadewi, Analisis Desain Sistem Fuzzy Menggunakan Toolbox Matlab. Yogyakarta: Graha Ilmu, 2002.

[24] M.N. Norazian, A. Mohd Mustafa Al Bakri, Y. Ahmad Shukri, R. Nor Azam, "Estimating Missing Data using Interpolation Texhnique: Effects on Fitting Distribution," Universiti Sains Malaysia, Nibong Tebal, 2011. 